\title{
Effects of Corruption on Tertiary School Enrolment in Africa
}

\author{
Idrissa Ouedraogo $0^{1,2^{*}} \quad$ Issa Dianda $^{3} \quad$ Constant Fouopi Djiogap ${ }^{2}$ \\ 1.Institute of Governance, Humanities and Social Sciences, The Pan African University, Yaoundé \\ 2.Faculty of Economics and Management, The University of Yaoundé II, Cameroon \\ 3.Department of Economics and Management, Thomas Sankara University
}

\begin{abstract}
This paper empirically analyses the effects of control of corruption on tertiary school enrolment in a panel of 44 African countries over the period 1996-2016. Using system Generalized method of moments and controlling for a large number of other determinants of tertiary school enrolment, it finds that, over the sample period, control of corruption has a substantial positive effect. This is probably because control of corruption increases public spending level and effectiveness on tertiary education, increases the return on tertiary education, and ultimately fosters the access to tertiary education specially the poorer strata in the African economies. In the light of this result, an intensification of control of corruption in Africa is imperative to improve the tertiary school enrolment.
\end{abstract}

Keywords: Control of corruption, tertiary school enrolment, System GMM, Africa

DOI: $10.7176 / \mathrm{JEP} / 11-29-06$

Publication date:October $31^{\text {st }} 2020$

\section{Introduction}

In a knowledge and competitive economy, tertiary education plays a key role in the process of economic growth and sustainable development. It leads to a more entrepreneurial and civic society (Asamoah \& Mackin, 2015). Moreover, a labour force with a tertiary education level is more productive and able to adapt technologies and innovation (Bloom, Canning, Chan, \& Luca, 2014). Similarly, the structural transformation is strongly associated with the labour force benefiting from tertiary education (Darvas, Gao, Shen, \& Bawany, 2017). Therefore, tertiary education can make an important contribution for building a stronger society, ending extreme poverty, and boosting shared prosperity (World Bank, 2017). At individual level, tertiary education leads to robust private returns to graduates and the average returns exceed those at the primary and secondary level (Montenegro \& Patrinos, 2014). The positive effect of tertiary education on economic growth is well established in empirical literature in mixed panel studies (Chatterji,1998) and evaluations based on African countries (Gyimah-Brempong, Paddison, \& Mitiku, 2006; Okuneye \& Adelowokan, 2014).

In view of this pivotal role, the factors determining the tertiary school enrolment have been the subject of reflection in the literature. In recent decades, corruption has been identified as a key determinant of tertiary education. Corruption can be defined as the abuse of authority for personal as well as material gain (Heyneman, 2004). In tertiary education sphere, it includes, among other, embezzlement, patronage, cronyism, sexual misconduct, illicit payments in recruitment and admissions, nepotism in tenured postings, bribery in on-campus accommodation and grading, political and corporate undue influence in research, plagiarism, ghost authorship and editorial misconduct in academic journals (Osipian, 2007; Transparency International, 2013). But why might there be an effect of corruption on tertiary education?

There are several channels through which corruption influences tertiary education. Firstly, corruption acts as an added tax, and therefore is a barrier to access to tertiary education, especially for students from poorer strata of society (Borcan, Lindahl, \& Mitrut, 2017). By limiting access to tertiary education, corruption reduces its enrolment rates.

Secondly, corruption lowers the return on education, discourages further education and reducing the enrolment rates. Education is as a component of human capital and considered as an investment (Becker, 1964). The trade-off between costs and benefits determines the optimal number of years of schooling. Corruption increases the uncertainty of success in the labour market after graduating and reduce the economic rate of return on tertiary education investment by public institutions and individual students (Duerrenberger \& Warning, 2018; Transparency International, 2013). Likewise, corruption contributes to the collapse of values by negatively influencing the accumulation of human capital. It discourages individuals from fully investing in tertiary education and pursuing it to the end because there is no opportunity offered to them to benefit from these long-term investments (Sen, 2015). It undermines incentives that motivate young people to work hard while teaching them that there are easier ways to achieve success (Rumyantseva, 2005). Seka (2013) argues that in an environment where corruption reigns, the attraction of easy gain by unsavoury practices of less deserving students can lead the most deserving ones to halt studies quickly to join the gang of rich mafia, and this, by pure mimicry, with regard to the expected immediate benefits. In such environment, very talented students, who otherwise could have pushed further their studies, suddenly dropout when they compare the level of wellbeing of those who are well educated with that of those who are not but enriched through corruption. They join the later in their corruptive activities. 
Seka (2013) also notes that in the public service, some agents in certain functions do not want promotion. They manage not to take exams that could allow them to rise in rank, because this would prevent them from having access to annuity situations. Therefore, they refuse to do continuous training in order to increase their human capital, refusing knowledge, perfection and remaining in mediocrity.

Thirdly, corruption affects tertiary education through its effect on public spending allocation and tax revenue. In a corrupt sphere, the existence of rent seeking creates distortions in the allocation of public spending (Hessami, 2014). The sectors conducive to corrupt transactions and for which the rent exists and can be easily extracted and concealed are prioritized. Education sector offer fewer opportunities for rent-seeking and is not prioritized (Hessami, 2014; Mauro, 1998). In the same vein, high level of corruption leads to the evasion of taxes and consequently reduce the volume of funds available to finance education.

Lastly, a country with limited corruption offers quality services including those related to education. For example, public spending on primary education becomes more effective in increasing primary education attainment in countries with lower corruption (Rajkumar \& Swaroop, 2008).

However, moral condemnation of corruption should not prevent the point that, in economic terms, its harmfulness is not necessarily proven. For example, Huntington and Fukuyama (2006) and Leff (1964) seem to see benefits in corruption. Indeed, corruption can reduce state constraints by speeding up transactions. Bribes can be a mechanism to overcome overly centralized government bureaucracy, red tape and waiting times. Bribe can be an effective solution to acquiring an education service that would otherwise not be available and accessible. For example, in a country where individuals and entrepreneur want to build schools, in an overly centralized government bureaucracy, corruption may speed up the possibility for them to be able to build their schools in a reasonable time allowing students to go in those schools.

In Africa, and particularly in sub-Saharan Africa (SSA), tertiary enrollment rate is still the lowest in the world. According to World Bank statistics, the tertiary enrolment rate across SSA in 2018 is 9.38\%, or almost the world average in 1970 and well below the world average of 38.04\% (World Bank, 2020a). At the same time, SSA, with an average of 32 out of 100 has the lowest-scoring region on the corruption perception index in 2019 (Transparency International, 2020). The Global Corruption Barometer Africa finds more than one in four people (28\%) who accessed public services, such as education, paid a bribe in the preceding year. This equates to approximately 130 million citizens in the 35 African countries surveyed. A majority of African citizens (55\%) think that corruption increased in their country in the previous 12 months, while far fewer think it declined (23\%) (Pring \& Vrushi, 2019).

The low rate of tertiary education in Africa, combined with the prevalence of corruption legitimizes an empirical investigation of the link between corruption and the rate of tertiary education. This paper explores the effects of corruption on tertiary school enrolment rate. It is in line with the work of Seka (2013) who highlighted the negative effect of corruption on tertiary education in a sample of 38 developed and developing countries using Ordinary least squares (OLS) in a cross-sectional data in 1998. Our paper differs from his study in four ways. First, we assess the link in a more homogeneous area that is Africa. Second, we study the effect of corruption on tertiary education not only among males and females jointly but also separately for females. Third, we use more recent data spanning from 1996-2016. Fourth, we use the system Generalized method of moments (system GMM) estimates proposed by la Blundell and Bond (1998) to account for endogeneity problems.

The remainder of the paper is organized as follows. While section 2 describes the methodology used for empirical investigation, section 3 presents and discusses the empirical findings. Section 4 concludes.

\section{Materials and method}

\subsection{Empirical Model Specification}

We test the hypothesis that corruption is detrimental to both tertiary school enrolment and female tertiary school enrolment. To do this, we estimate the effect of control of corruption on tertiary school enrolment in African economies. We estimate the following econometric model:

$$
E d u c_{i, t}=\alpha+\rho E d u c_{i, t-1}+\lambda \operatorname{Corr}_{i, t}+\gamma X_{i, t}+\eta_{i}+\mu_{t}+\varepsilon_{i, t}(1)
$$

In equation (1), $\mathrm{t}=1 \ldots, 23$ and $\mathrm{i}=1, \ldots, 44$ denote time and country, respectively. The variable $E d u c_{i, t}$ represents our measure of tertiary school enrolment from the World Bank (2020a) World Development Indicators (WDI). Its lagged value $E d u c_{i, t-1}$, the dynamic specification, is included on the right-hand side to accommodate dynamic accumulation of tertiary education. In addition, tertiary education may exhibit inertia in the sense that the current value may be determined by the past value of the variable because the tertiary education policies implemented take time to generate results. The variable $\operatorname{Corr}_{i, t}$ denotes control of corruption from the World Bank (2020b) Worldwide Governance Indicators (WGI). $\boldsymbol{X}_{\boldsymbol{i}, \boldsymbol{t}}$ is a set of control variables including public spending on tertiary education as a percentage of GDP, urban population, foreign direct investment net inflows as percentage 
of GDP, inflation rate, GDP per capita, Domestic credit provided to the private sector by banks, population growth rate, trade openness, and ethnic fractionalisation. $\eta_{i}$ and $\mu_{t}$ denote a full set of country and time fixed effects, respectively. $^{\varepsilon_{i, t}}$ is the error term.

\subsection{Presentation of variables}

The dependent variable is the gross tertiary school enrolment rate. In addition to the tertiary enrolment rate, which covers male and female jointly, we also use the female tertiary enrolment rate. This is because the education of girls has traditionally been neglected in many African countries. At higher education level, SSA has the lowest gender parity index $(0.75)$ in 2028 while the others regions have a well-balanced tertiary gender parity index (more than 1) (World Bank, 2020a).

Using the female tertiary enrolment rate as an alternative dependent variable enables us to gauge whether and to what extent corruption has been detrimental to this demographic group in particular.

The explanatory variable of interest is the control of corruption from the Worldwide Governance Indicators of the World Bank (2020b). It is the only indicators which covers all African countries and is the most widely used in the empirical literature. It is also easily accessible. For our variables, definitions, descriptive statistics and data sources are given in Table A1 of appendices.

We run the main specification of our regression without controls. Following the literature, we use many variables to control for the effects of factors that are potentially important determinants of tertiary education. These controls are added progressively to the main specification. This can be served as robustness check for the effects of control of corruption on tertiary school enrolment. We first control for government expenditure per student in tertiary education as a percentage of GDP per capita. Countries with higher expenditure per student in the tertiary education tend to have lesser school enrolment rates because this is likely to be a cost.

We also control for urbanisation rate. In general, in urban areas, access to education is better than in rural areas (Baldacci, Clements, Gupta, \& Cui, 2008). In particular, access to tertiary education is usually possible in urban areas since most universities and others tertiary education institutions are mostly located in urban areas. In line with this idea, we hypothesize that urbanization is favourable to tertiary school enrolment in Africa.

Additionally, we control for Foreign direct investment (FDI), net inflows in percentage of GDP per capita. In the empirical literature, some authors have shown that net capital inflows improve tertiary completion rates at the level of host countries (Egger et al., 2010; Zhuang, 2013) while others found that increase in FDI has a negative effect on tertiary education (Wang, 2011; Zhuang ,2016). We expect foreign direct investment net inflow to decrease tertiary school enrolment in Africa.

We also add inflation rate as another control variable. Berg (1981) studies the effect of inflation on tertiary education and argues that it negatively affects the return on investment in education. Heylen, Schollaert, Everaert and Pozzi (2003) study the effects of inflation on human capital formation and find that rising inflation fundamentally favours human capital formation. However, the effect of inflation on human capital development is negative when the inflation rate exceeds the $100 \%$ threshold. For an inflation rate below $15 \%$, its effect is not significant. We expect inflation to have a negative effect on tertiary school enrolment rates.

We control of GDP per capita because it has a positive effect on schooling (Mincer, 1996). The increase in per capita income gives citizens more leeway to invest in higher education given its cost.

Domestic credit provided to the private sector by banks is also added as a control variable. It is a proxy for borrowing constraints. Cameron and Taber (2004) show that credit market restrictions do not generate large inefficiencies in the US education market. Therefore, partnership-based policies to improve access to the credit market would not have had a significant effect on the education acquired by individuals. Chein and Pinto (2017) find no evidence of credit constraint in the education decision at the tertiary education level in Brazil. However, Mimoun (2008) estimates the effect of credit constraints on tertiary education enrolment and show that credit market restrictions have a negative effect on investment in human capital. We expect to have positive effects on access to credit on tertiary school enrolment in African economies. Where low-income households have broad access to formal and informal credit markets, their children are not forced to work to help out at home. They can enrol in school and go as far as possible in their education.

We also include population growth rate. Lower population growth can lead to a higher tertiary enrolment rate. This is because both parents and societies face a trade-off between child quantity and quality: The lower the number of children in a family, the more they are usually able to invest into each of them (Becker \& Lewis,1973; Hanushek, 1992).

Finally, we use ethnic fractionalisation as a proxy of ethnic diversity. Churchill, Madhoo and Nath (2020) also examine the effects of ethnic diversity on education in 30 Indian States and 557 districts. Their findings suggest development-enhancing effects of ethnic diversity on education. We also expect ethnic diversity to favourably affect tertiary education in Africa. 
Our panel annual data covers 44 African countries (for a list of countries, see Appendix B) over the time period 1996-2016. With respect to both countries and years, the size of our sample is determined by data availability only.

There is a substantial variation in both the control of corruption measure and the two enrolment variables. Specifically, on a -2.5 to 2.5 scale, control of corruption ranges from -1.723 to 1.217 (Table A1). The tertiary enrolment rate ranges from $0.321 \%$ to $42.629 \%$, while the female tertiary enrolment rate ranges from $0.147 \%$ to $53.6 \%$.

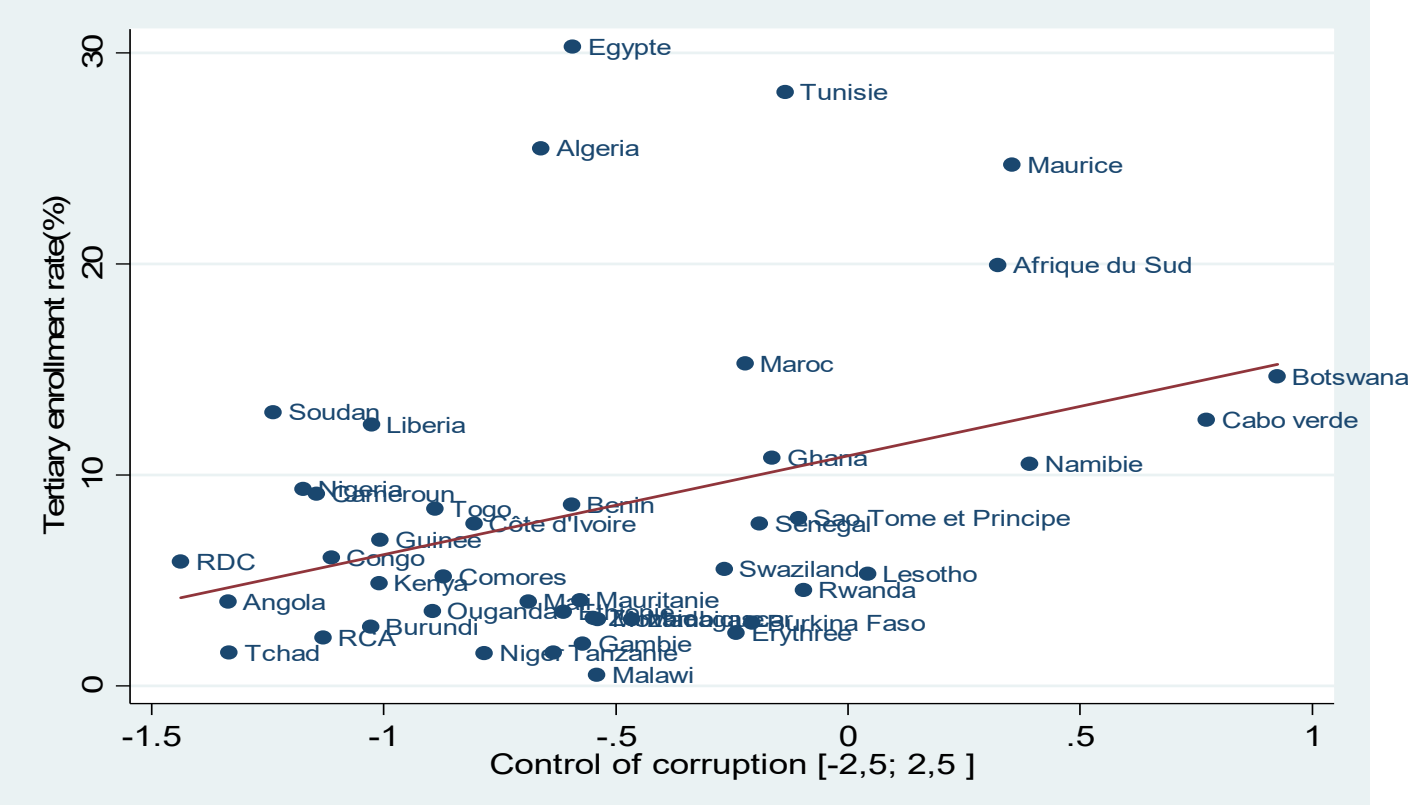

Notes : 44 African countries. Data from the period 1996 to 2016 . The regression represented by the fitted line yields a coefficient on control of corruption of 0.515 (robust standard error $=0.050$ ), $\mathrm{R}^{2}=0.339$.

Source: Authors usind data from WGI and WDI (World Bank, 2020a,2020b)

Figure 1: Control of corruption and tertiary enrolment rate in African economies, 1996-2016

The bivariate associations between control of corruption and tertiary enrolment rates and female tertiary enrolment rates in figures 1 and 2 use country averages over the sample period 1996-2016 and show a positive relationship. Over the sample period, African countries that have a good control of corruption tend to have a higher tertiary enrolments rates, both among male and female combined as well as among female only. However, a counter-intuitive finding should be noted among the 5 countries with the highest tertiary education rates. The 3 North African countries (Algeria, Tunisia, Egypt) have higher levels of corruption and higher education rates. Meanwhile, the two countries of Sub-Saharan Africa (Mauritius, South Africa), although having relatively low levels of corruption compared to the 3 above-mentioned countries, have lower tertiary education rates. 


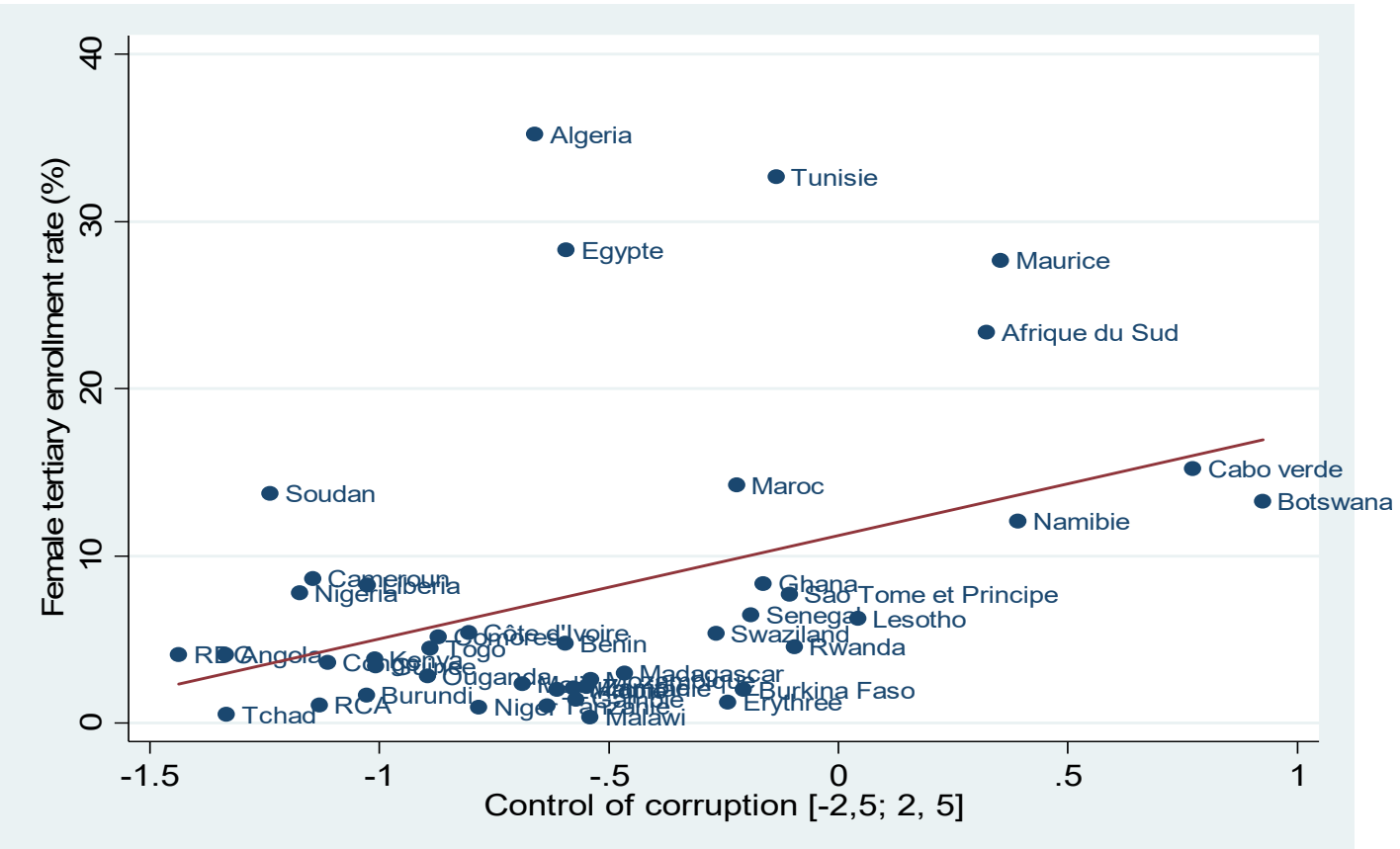

Notes : 44 african countries. Data from the period 1996 to 2016. The regression represented by the fitted line yields a coefficient on control of corruption of 0.807 (robust standard error $=0.075$ ), $\mathrm{R}^{2}=0.384$.

Source: Authors using data from WGI and WDI (World Bank, 2020a,2020b)

Figure 2. Control of corruption and female tertiary enrolment rate in African economies, 1996-2016

\subsection{Estimation technique}

For the estimation technique, we use a GMM estimator to control for possible endogeneity bias due to reverse causality, and measurements errors. For example, causality may not only run from control of corruption to education but also vice versa. Education can also affect corruption. According to Gupta et al. (2001), a low level of education could also create an environment conducive to corruption. Conversely, when a population is better educated, it may offer a better chance to control corruption. It is also generally accepted that more educated citizens are less tolerant of corruption (Swamy et al., 2001; Truex, 2011). Therefore, as argue Asongu and Nwachukwu (2015), education is a powerful tool in the fight against corruption. In this vein, Cheung and Chan (2008) state that as the number of people participating in tertiary education increased, the incidence of corruption occurring in the countries decreased. This is also supported by Lipset (1960) in his theory of modernization. There are also possible measurement errors of macroeconomic variables presented in section 5 .

Using GMM estimator means we take first differences of the regression equation to purge time-invariant fixed effects. We then choose suitably lagged levels of the variables as internal instruments. Following Blundell and Bond (1998), to improve the finite sample properties of the estimator, we augment the equation in first differences with that in levels where lagged first differences serve as instruments. The validity of the second set of instruments rests on the assumption that changes in the instrumenting variables are uncorrelated with $\eta_{\mathrm{i}}$. Following Blundell and Bond (1998), we report two specification tests, namely, the Hansen (1982) test of overidentifying restrictions, which evaluates the validity of the instruments, and a test that the error term exhibits no second-order serial correlation (see table 1 and 2).

Following the advice by Roodman (2009a) we add time fixed to control for correlation across individuals in the error term. Finally, we apply Windmeijer's (2005) correction to our standards errors to correct the finite sample bias in the two-step standard errors. As previously stated, we control for most major determinants of school enrolment that have been found in the previous literature. We did this by including them progressively in our preliminary specification.

During the estimation of equation (1), as variables are added, the number of countries decreases: some countries do not have many observations for some variables. We would have liked to make the estimates taking into account other heterogeneities (apart from the differentiation of total tertiary education versus tertiary education of women) such as the sub-Saharan Africa and North Africa declination, unfortunately the availability of data, does not allow for this. In addition, following the technical condition of use of GMM set by Roodman (2009a, 2009b) who points out that this method is suitable for panel data structures in which the study period (T) is shorter than the sample size $(\mathrm{N})$ does not allow such heterogenous analysis. 


\section{Results and discussion}

The results of our regressions are presented in table 1 for both male and female tertiary school enrolment and in table 2 for female tertiary school enrolment only.

Table 1: System-GMM estimates of control of corruption on tertiary school enrolment in Africa, 1996-2016

\begin{tabular}{|c|c|c|c|c|c|c|c|c|c|c|}
\hline & (1) & (2) & (3) & (4) & (5) & (6) & (7) & (8) & (9) & (10) \\
\hline \multirow{3}{*}{ Lagged dependent variable } & $0.965 * * *$ & $0.643 * * *$ & $0.645 * * *$ & $0.407^{* *}$ & $0.589^{* *}$ & $0.757 * * *$ & $0.588^{* *}$ & $0.593^{*}$ & $0.608^{*}$ & $0.813 * * *$ \\
\hline & $(0.017)$ & $(0.138)$ & $(0.157)$ & $(0.170)$ & $(0.270)$ & $(0.198)$ & $(0.266)$ & $(0.301)$ & $(0.315)$ & $(0.103)$ \\
\hline & $0.046 * *$ & $0.188 * *$ & $0.143 *$ & $0.165 * * *$ & $0.183 * *$ & $0.088 * *$ & $0.126 * *$ & $0.123 * *$ & $0.122 * * *$ & $0.062 *$ \\
\hline \multirow[t]{2}{*}{ Control of corruption } & $(0.019)$ & $(0.079)$ & $(0.083)$ & $(0.056)$ & $(0.086)$ & $(0.038)$ & $(0.052)$ & $(0.050)$ & $(0.041)$ & $(0.032)$ \\
\hline & & -0.195 & -0.123 & -0.024 & -0.076 & -0.030 & -0.076 & -0.079 & -0.060 & -0.025 \\
\hline \multirow[t]{2}{*}{ Expenditure per student } & & $(0.128)$ & $(0.128)$ & $(0.093)$ & $(0.098)$ & $(0.048)$ & $(0.098)$ & $(0.111)$ & $(0.090)$ & $(0.022)$ \\
\hline & & & 0.248 & $0.623 * *$ & 0.340 & $0.141^{* *}$ & 0.198 & $0.194 *$ & $0.207^{*}$ & $0.210^{* *}$ \\
\hline \multirow[t]{2}{*}{ Urbanisation rate } & & & $(0.174)$ & $(0.228)$ & $(0.218)$ & $(0.069)$ & $(0.125)$ & $(0.096)$ & $(0.106)$ & $(0.099)$ \\
\hline & & & & $-0.061 * * *$ & $-0.047 * *$ & $-0.031^{*}$ & $-0.042 * *$ & $-0.044 * *$ & $-0.043^{*}$ & -0.014 \\
\hline \multirow[t]{2}{*}{ Foreign direct Investment } & & & & $(0.021)$ & $(0.021)$ & $(0.017)$ & $(0.019)$ & $(0.019)$ & $(0.021)$ & $(0.009)$ \\
\hline & & & & & 0.001 & -0.001 & 0.002 & 0.002 & 0.001 & $4.28 \mathrm{e}-05$ \\
\hline \multirow[t]{2}{*}{ Inflation rate } & & & & & $(0.003)$ & $(0.002)$ & $(0.003)$ & $(0.003)$ & $(0.003)$ & $(0.002)$ \\
\hline & & & & & & 0.081 & 0.195 & 0.176 & 0.132 & -0.012 \\
\hline GDP per capita & & & & & & $(0.131)$ & $(0.194)$ & $(0.225)$ & $(0.227)$ & $(0.049)$ \\
\hline $\begin{array}{l}\text { Domestic credit provided to the private sector } \\
\text { by banks }\end{array}$ & & & & & & & $\begin{array}{l}-0.002 \\
(0.002)\end{array}$ & $\begin{array}{l}-0.002 \\
(0.002)\end{array}$ & $\begin{array}{l}-0.002 \\
(0.002)\end{array}$ & $\begin{array}{l}-0.001 \\
(0.001)\end{array}$ \\
\hline & & & & & & & & -0.033 & -0.100 & -0.054 \\
\hline Population growth rate & & & & & & & & $(0.048)$ & $(0.061)$ & $(0.039)$ \\
\hline Trade Onenness & & & & & & & & & $\begin{array}{c}0.027 \\
(0.126)\end{array}$ & $\begin{array}{l}-0.028 \\
0.068)\end{array}$ \\
\hline Ethnic & & & & & & & & & & $-0.247 * *$ \\
\hline fractionalisation & & & & & & & & & & $(0.104)$ \\
\hline Constant & $\begin{array}{l}0.161 * * * \\
(0.0374))\end{array}$ & $\begin{array}{l}1.701 * * \\
(0.814)\end{array}$ & $\begin{array}{c}0.464 \\
(1.130)\end{array}$ & $\begin{array}{l}-0.891 \\
(1.060)\end{array}$ & $\begin{array}{l}0.0553 \\
(0.630)\end{array}$ & $\begin{array}{l}-0.408 \\
(0.724)\end{array}$ & $\begin{array}{l}-0.963 \\
(1.183)\end{array}$ & $\begin{array}{l}-0.770 \\
(1.211)\end{array}$ & $\begin{array}{l}-0.627 \\
(1.129)\end{array}$ & $\begin{array}{l}0.242 \\
(0.263)\end{array}$ \\
\hline Observations & 456 & 233 & 233 & 138 & 125 & 125 & 120 & 119 & 117 & 117 \\
\hline Number of countries & 44 & 44 & 44 & 44 & 44 & 44 & 44 & 44 & 44 & 44 \\
\hline Number of instruments & 13 & 10 & 11 & 20 & 13 & 14 & 15 & 17 & 18 & 19 \\
\hline Arellano-Bond test AR(2) & 0.246 & 0.243 & 0.378 & 0.419 & 0.117 & 0.113 & 0.240 & 0.248 & 0.250 & 0.151 \\
\hline Hansen p-value & 0.389 & 0.633 & 0.610 & 0.424 & 0.337 & 0.194 & 0.354 & 0.412 & 0.380 & 0.664 \\
\hline
\end{tabular}

Note : Standard errors in parentheses. They are corrected by using the Windmeijer (2005) finite sample procedure. $* * * \mathrm{p}<0.01$, significant at $1 \%$; ${ }^{*} \mathrm{p}<0.05$, significant at $5 \%,{ }^{*} \mathrm{p}<0.1$ significant at $10 \%$. Controls are added progressively and cumulatively.

Source: Authors' estimation.

Before we discuss the results from our regressions, let us briefly take a look at the validity of our model. We can see from tables 1 and 2 that lagged dependent variable is statistically significant for all regressions showing that a dynamic specific was suitable. This shows that accumulation of tertiary education is dynamic and that tertiary education exhibits inertia because current tertiary education may be determined by the past value of this education since tertiary education policies implemented take time to generate results. In all regressions, we can also see that the Hansen test $p$-value indicates the validity of the overidentifying restrictions: Hansen- $p$ value $\geq 10$. Moreover, there is no evidence for second -order autocorrelation: AR2-p value $\geq 10$. The number of countries is also more than the number of instruments, indicating that there is no problem of instruments proliferation.

Concerning our multivariate regressions shown in table 1 and 2, while column 1 from table 1 presents the results from our baseline specification, columns 2 to 10 present the results from our robustness checks. While table 1 reports the results from the regressions to explain the tertiary school enrolment rate, table 2 reports the results from the regressions to explain the female tertiary school enrolment rate. Each regression to explain the female tertiary school enrolment rate in table 2 uses the same control variables as the corresponding regression to explain the tertiary enrolment rate presented in table 1.

In each regression, the coefficient on control of corruption is positive and statistically significant, suggesting that, over 1996-2016, control of corruption has a favourable effect on both the tertiary and the female tertiary enrolment rates. Our regression results corroborate the hypothesis that corruption is detrimental to tertiary education and female tertiary education. As explained in the introduction (section 1), as an added tax, corruption can act as a barrier for poor people to access to tertiary education. In addition, corruption can negatively affect tertiary school enrolment through its deleterious effect on public spending allocation and tax revenue. For example, when a public official misappropriates public money intended for the construction of academic infrastructure, this negatively affects the provision of tertiary education and thus limits the possibility for people to have access to this education. Furthermore, corruption can also lower the return on education and discourages further education, thus reducing the enrolment rates. In a corrupt environment characterised by the lure of easy gain; students lose interest in continuing their studies. 
Table 2: System-GMM estimates of control of corruption on female tertiary school enrolment in Africa, 19962016

\begin{tabular}{|c|c|c|c|c|c|c|c|c|c|c|}
\hline & $(1)$ & (2) & (3) & (4) & (5) & (6) & (7) & $(8)$ & $(9)$ & (10) \\
\hline & $0.819^{* * *}$ & $0.451 * *$ & $0.311 * *$ & $0.536^{* * *}$ & $0.305 * *$ & $0.867 * * *$ & $0.819^{* * *}$ & $0.793 * * *$ & $0.784 * * *$ & $0.834 * * *$ \\
\hline \multirow{2}{*}{ Lagged dependent variable } & $(0.081)$ & $(0.194)$ & $(0.117)$ & $(0.174)$ & $(0.132)$ & $(0.144)$ & $(0.088)$ & $(0.103)$ & $(0.100)$ & $(0.056)$ \\
\hline & $0.118 *$ & $0.386 * *$ & $0.412 * * *$ & $0.243 * * *$ & $0.455 * * *$ & $0.121 * *$ & $0.088 * *$ & $0.109 * * *$ & $0.115 * * *$ & $0.075 * *$ \\
\hline \multirow[t]{2}{*}{ Control of corruption } & $(0.069)$ & $(0.170)$ & $(0.125)$ & $(0.076)$ & $(0.126)$ & $(0.059)$ & $(0.036)$ & $(0.034)$ & $(0.035)$ & $(0.034)$ \\
\hline & & $-0.295 * *$ & $-0.226^{*}$ & -0.112 & -0.184 & -0.042 & $-0.046^{*}$ & -0.073 & -0.072 & $-0.053 *$ \\
\hline \multirow[t]{2}{*}{ Expenditure per student } & & $(0.144)$ & $(0.130)$ & $(0.095)$ & $(0.112)$ & $(0.073)$ & $(0.023)$ & $(0.055)$ & $(0.049)$ & $(0.029)$ \\
\hline & & & $0.603 * *$ & $0.483^{*}$ & $0.544 * *$ & 0.121 & 0.108 & 0.126 & $0.133 * *$ & $0.179 * *$ \\
\hline \multirow[t]{2}{*}{ Urbanisation rate } & & & $(0.224)$ & $(0.260)$ & $(0.237)$ & $(0.088)$ & $(0.084)$ & $(0.087)$ & $(0.062)$ & $(0.071)$ \\
\hline & & & & $-0.029 *$ & $-0.0568 * *$ & $-0.0201 * *$ & -0.012 & $-0.018^{*}$ & $-0.019 *$ & -0.013 \\
\hline \multirow[t]{2}{*}{ Foreign direct Investment } & & & & $(0.016)$ & $(0.025)$ & $(0.009)$ & $(0.008)$ & $(0.011)$ & $(0.010)$ & $(0.009)$ \\
\hline & & & & & 0.001 & -0.000 & $-1.24 \mathrm{e}-05$ & -0.000 & -0.000 & 0.000 \\
\hline \multirow[t]{2}{*}{ Inflation rate } & & & & & $(0.003)$ & $(0.002)$ & $(0.003)$ & $(0.003)$ & $(0.002)$ & $(0.002)$ \\
\hline & & & & & & -0.008 & 0.096 & 0.047 & 0.049 & -0.000 \\
\hline GDP per capita & & & & & & $(0.143)$ & $(0.088)$ & $(0.115)$ & $(0.113)$ & $(0.082)$ \\
\hline Domestic credit provided to the & & & & & & & -0.002 & -0.001 & -0.001 & -0.001 \\
\hline \multirow[t]{2}{*}{ private sector by banks } & & & & & & & $(0.002)$ & $(0.0007)$ & $(0.001)$ & $(0.001)$ \\
\hline & & & & & & & & -0.050 & $-0.066 * *$ & $-0.055^{*}$ \\
\hline \multirow[t]{2}{*}{ Population growth rate } & & & & & & & & $(0.037)$ & $(0.027)$ & $(0.027)$ \\
\hline & & & & & & & & & -0.006 & 0.001 \\
\hline Openness & & & & & & & & & $(0.088)$ & $(0.077)$ \\
\hline Ethnic fractionalisation & & & & & & & & & & $\begin{array}{l}-0.191 * * \\
(0.070)\end{array}$ \\
\hline Constant & $\begin{array}{l}0.401 * * * \\
(0.139)\end{array}$ & $\begin{array}{l}2.396 * * \\
(0.927)\end{array}$ & $\begin{array}{l}0.163 \\
(1.255)\end{array}$ & $\begin{array}{l}-0.341 \\
(1.042)\end{array}$ & $\begin{array}{l}0.285 \\
(1.216)\end{array}$ & $\begin{array}{l}0.179 \\
(0.837)\end{array}$ & $\begin{array}{l}-0.480 \\
(0.632)\end{array}$ & $\begin{array}{l}0.044 \\
(0.564)\end{array}$ & $\begin{array}{l}0.059 \\
(0.769)\end{array}$ & $\begin{array}{l}0.175 \\
(0.534)\end{array}$ \\
\hline Observations & 404 & 207 & 207 & 128 & 116 & 116 & 111 & 110 & 108 & 108 \\
\hline Number of countries & 44 & 44 & 44 & 44 & 44 & 44 & 44 & 44 & 44 & 44 \\
\hline Number of instruments & 7 & 10 & 20 & 15 & 8 & 18 & 16 & 22 & 24 & 22 \\
\hline Arellano-Bond test for AR (2) & 0.495 & 0.794 & 0.577 & 0.608 & 0.720 & 0.883 & 0.831 & 0.895 & 0.879 & 0.906 \\
\hline Hansen p-value & 0.175 & 0.417 & 0.636 & 0.528 & 0.629 & 0.202 & 0.572 & 0.488 & 0.658 & 0.548 \\
\hline
\end{tabular}

Note: Standard errors in parentheses. They are corrected by using the Windmeijer (2005) finite sample procedure. $* * * \mathrm{p}<0.01$, significant at $1 \%$; ** $\mathrm{p}<0.05$, significant at $5 \%, * \mathrm{p}<0.1$ significant at $10 \%$. Controls are added progressively and cumulatively. All regressions contain a constant term. Each regression of female tertiary enrolment rate uses the same control variables as the regression of tertiary enrolment rate presented in the same column in Table 1.

Source: Authors' estimation.

Talented students who initially would like to study for long periods of time are hastily judged to be too long when they compare the standard of living of those who have already done so with those who have not but are rich in corruption. The high drop-out rate that has become commonplace in African universities can be explained by corruption. Our result is in line with Seka (2013) who finds corruption to be detrimental to tertiary school enrolment in a sample of 38 developed and developing countries using OLS in a cross-sectional data from 1998. They are also in accordance with results by Dridi (2014). This author demonstrates in a sample of 85 developed and developing countries under the period 1980-2002 that access to secondary schooling is significantly and negatively affected by increased corruption. Our results corroborate those of Duerrenberger and Warning (2018) who, using data from 88 developing countries from 2005 to 2012, found that corruption negatively correlates with expected years of schooling.

Although our results accord with other studies, our paper adds to this literature in several respects, most importantly by using system GMM to account for potential endogeneity bias, a much larger number of controls and by estimating the effect of corruption on tertiary education not only among males and females jointly but also separately for females in Africa in a more recent data spanning from 1996-2016.

Finally, we briefly comment on the estimates for the control variables (tables 1 and 2). Interestingly, very few of them are statistically significant and robust to the inclusion of additional controls or the tertiary and female tertiary education. One of the most robust results among the controls is that, during our sample period, ethnic fractionalisation is associated with a lower tertiary enrolment rate. Replacing ethnic fractionalisation by religion fractionalisation does not qualitatively change the result. This suggest that cultural diversity unfavourably affects education. This result does not accord with Alesina et al. (2003) and Gruber (2005) who suggest that, in their cases, religious pluralism might favourably affect education.

\section{Conclusion}

This paper investigates the effects of corruption on tertiary school enrolment in Africa. The analyse uses annual data on a panel of 44 countries over the time period 1996-2016 and system GMM estimator. The estimated effects suggest that corruption hinders tertiary school enrolment in the region. This finding persists if we use more controls 
and female tertiary school enrolment rates. For countries in the region, this finding implies that controlling corruption will probably allow many people to access tertiary education. If a government in the region decides to increase access in tertiary education, it seems relevant to implement successful control of corruption policies.

\section{Appendices}

Table A1: Variables sources and definitions

\begin{tabular}{|c|c|c|c|c|c|c|c|c|c|}
\hline Variable & Definition & Obs. & \multicolumn{2}{|c|}{ Mean } & Std. dev. & Min. & & Max. & Source \\
\hline $\begin{array}{l}\text { Tertiary school } \\
\text { enrolment rate }(\%)\end{array}$ & $\begin{array}{l}\text { Boys and girls enrolled in tertiary } \\
\text { education, regardless of age, as a } \\
\text { percentage of girls in the age group } \\
\text { that officially corresponds to this } \\
\text { level of education. }\end{array}$ & 589 & \multicolumn{2}{|c|}{9.010} & 9.194 & .321 & & 42.629 & $\begin{array}{l}\text { World } \\
\text { Bank } \\
(2020 \mathrm{a})\end{array}$ \\
\hline $\begin{array}{l}\text { Female tertiary } \\
\text { school } \\
\text { enrolment rate } \\
(\%)\end{array}$ & $\begin{array}{l}\text { Girls enrolled in tertiary education, } \\
\text { regardless of age, as a percentage of } \\
\text { girls in the age group that officially } \\
\text { corresponds to this level of education. }\end{array}$ & 535 & \multicolumn{2}{|c|}{8.617} & 10.837 & .147 & & 53.600 & $\begin{array}{l}\text { World } \\
\text { Bank } \\
(2020 \mathrm{a})\end{array}$ \\
\hline $\begin{array}{l}\text { Control of } \\
\text { corruption }\end{array}$ & $\begin{array}{l}\text { It measures the extent to which public } \\
\text { power is exercised for private gain, as } \\
\text { well as "capture" of the state by elites } \\
\text { and private interests. It takes values } \\
\text { from }-2.5 \text { to }+2.5 \text { with a higher level } \\
\text { indicating more effort of to control } \\
\text { corruption. }\end{array}$ & 924 & \multicolumn{2}{|c|}{-.547} & .588 & \multicolumn{2}{|l|}{-1.723} & 1.217 & $\begin{array}{l}\text { World } \\
\text { Bank } \\
(2020 b)\end{array}$ \\
\hline $\begin{array}{l}\text { GDP per capita, } \\
\text { (constant } 2011 \\
\text { international \$) }\end{array}$ & $\begin{array}{l}\text { It is GDP per capita based on } \\
\text { purchasing power parity rates. }\end{array}$ & 910 & \multicolumn{2}{|c|}{3764.489} & 3595.059 & \multicolumn{2}{|l|}{508.334} & 19590.61 & $\begin{array}{l}\text { World } \\
\text { Bank } \\
(2020 \mathrm{a})\end{array}$ \\
\hline $\begin{array}{l}\text { Population growth } \\
\text { rate }(\%)\end{array}$ & $\begin{array}{l}\text { Annual growth rate of the population; } \\
\text { decimal fraction. }\end{array}$ & 919 & \multicolumn{2}{|c|}{2.428} & .954 & \multicolumn{2}{|l|}{-.617} & 8.118 & $\begin{array}{l}\text { World } \\
\text { Bank } \\
(2020 \mathrm{a})\end{array}$ \\
\hline $\begin{array}{l}\text { Government } \\
\text { expenditure per } \\
\text { student, tertiary ( } \% \\
\text { of GDP per capita) }\end{array}$ & $\begin{array}{l}\text { Government expenditure per student } \\
\text { is the average general government } \\
\text { expenditure per student in tertiary } \\
\text { education, expressed as a percentage } \\
\text { of GDP per capita. }\end{array}$ & 271 & \multicolumn{2}{|c|}{217.326} & 312.823 & \multicolumn{2}{|l|}{.034} & 2489.753 & $\begin{array}{l}\text { World } \\
\text { Bank } \\
(2020 \mathrm{a})\end{array}$ \\
\hline Trade openness & $\begin{array}{l}\text { Sum of exports and imports of goods } \\
\text { and services as a decimal fraction of } \\
\text { GDP. }\end{array}$ & 864 & \multicolumn{2}{|c|}{69.486} & 33.730 & \multicolumn{2}{|l|}{17.859} & 311.354 & $\begin{array}{l}\text { World } \\
\text { Bank } \\
(2020 \mathrm{a})\end{array}$ \\
\hline Urbanisation rate & $\begin{array}{l}\text { People living in urban areas as a } \mathrm{d} \\
\text { fraction of the total population. }\end{array}$ & cimal & \multicolumn{2}{|c|}{919} & 37.952 & 15.492 & 7.412 & 71.459 & $\begin{array}{l}\text { World } \\
\text { Bank } \\
(2020 \mathrm{a})\end{array}$ \\
\hline \multicolumn{10}{|c|}{ able A1 (Continued) } \\
\hline Variable & Definition & & & Obs. & Mean & $\begin{array}{l}\text { Std. } \\
\text { dev. }\end{array}$ & Min. & Max. & Source \\
\hline $\begin{array}{l}\text { Foreign direct } \\
\text { investment, } \\
\text { net inflows }(\% \text { of } \\
\text { GDP) }\end{array}$ & \multicolumn{4}{|c|}{$\begin{array}{l}\text { Foreign direct investment are the net inflows of } \\
\text { investment to acquire a lasting management } \\
\text { interest (10 \% or more of voting stock) in an } \\
\text { enterprise operating in an economy other than that } \\
\text { of the investor. It is the sum of equity capital, } \\
\text { reinvestment of earnings, other long-term capital, } \\
\text { and short-term capital as shown in the balance of } \\
\text { payments. This series shows net inflows (new } \\
\text { investment inflows less disinvestment) in the } \\
\text { reporting economy from foreign investors, and is } \\
\text { divided by GDP. }\end{array}$} & 10.328 & 16.207 & -8.703 & 103.337 & $\begin{array}{l}\text { World } \\
\text { Bank } \\
(2020 a)\end{array}$ \\
\hline $\begin{array}{l}\text { Domestic credit } \\
\text { provided to the } \\
\text { private sector by } \\
\text { banks }(\% \text { of GDP) }\end{array}$ & \multicolumn{4}{|c|}{$\begin{array}{l}\text { Domestic credit to private sector by banks refers to } \\
\text { financial resources provided to the private sector } \\
\text { by other depository corporations (deposit taking } \\
\text { corporations except central banks), such as through } \\
\text { loans, purchases of nonequity securities, and trade } \\
\text { credits and other accounts receivable, that establish } \\
\text { a claim for repayment. For some countries these } \\
\text { claims include credit to public enterprises. }\end{array}$} & 36.790 & 26.312 & 1.855 & 143.656 & $\begin{array}{l}\text { World } \\
\text { Bank } \\
(2020 \mathrm{a})\end{array}$ \\
\hline $\begin{array}{l}\text { Ethnic } \\
\text { fractionalisation }\end{array}$ & \multicolumn{4}{|c|}{$\begin{array}{l}\text { The index of ethnic fractionalization that captures } \\
\text { the probability that two randomly selected persons } \\
\text { from a given country will not belong to the same } \\
\text { ethnic group. }\end{array}$} & .629 & .249 & 0 & .930 & $\begin{array}{l}\text { Alesina } \\
\text { et al. } \\
(2003)\end{array}$ \\
\hline Inflation rate & \multicolumn{3}{|c|}{$\begin{array}{l}\text { Annual change in the consumer price index; } \\
\text { decimal fraction. }\end{array}$} & 823 & 15.949 & 11.455 & -60.496 & 98.224 & $\begin{array}{l}\text { World } \\
\text { Bank } \\
(2020 \mathrm{a})\end{array}$ \\
\hline
\end{tabular}


South Africa, Algeria, Angola, Benin, Botswana, Burkina Faso, Burundi, Cape Verde, Cameroon, Comoros, Congo, Ivory Coast, Egypt, Eritrea, Ethiopia, The Gambia, Ghana, Guinea, Kenya, Lesotho, Liberia, Madagascar, Malawi, Mali, Morocco, Mauritius, Mauritania, Mozambique, Namibia, Niger, Nigeria, Uganda, Central African Republic, Democratic Republic of Congo, Rwanda, Sao Tome and Principe, Senegal, Sudan, Swaziland, Tanzania, Chad, Togo, Tunisia, Zambia.

\section{References}

Alesina, A., Devleeschauwer, A., Easterly, W., Kurlat, S., \& Wacziarg, R 2003). Fractionalization. Journal of Economic Growth, 8(2), 155-194.

Arellano, M. \& Bond, S., (1991). Some Tests of Specification for Panel Data: Monte Carlo Evidence and an Application to Employment Equations. Review of Economic Studies,58(2), 277-97.

Asamoah, M. K., \& Mackin, E. E. (2015). Breaking the Fetters of Higher Education in Sub-Saharan Africa. International Journal of Educational Administration and Policy Studies, 7(1), 6-16.

Asongu, S., \& Nwachukwu, J. C. (2015). The Incremental Effect of Education on Corruption: Evidence of Synergy from Lifelong Learning. Economics Bulletin, 35(4), 2288-2308. doi:10.2139/ssrn.2661448

Baldacci, E., Clements, B., Gupta, S., \& Cui, Q. (2008). Social Spending, Human Capital, and Growth in Developing Countries. World Development, 36(8), 1317-1341.

Becker, G. S. and H. G. Lewis (1973). On the Interaction between the Quantity and Quality of Children. Journal of Political Economy, 81(2, 2), S279-S288.

Becker, G. S. (1964). Human capital:A theorical and empirical analysis with special reference to education. National Bureau of Economic Research, New York.

Berg, I. (1981). The Effects of inflation on and in higher Education. The Annals of the American Academy of Political and Social Science, 456, 99-111.

Bloom, D. E., Canning, D., Chan, K. J., \& Luca, D. L. (2014). Higher Education and Economic Growth in Africa. International Journal of African Higher Education, 1(1), 22-57.

Blundell, R. \& Bond, S., (1998). Initial conditions and moment restrictions in dynamic panel data models. Journal of Econometrics, 87(1),115-143.

Borcan, O., Lindahl, M., \& Mitrut, A. (2017). Fighting Corruption in Education:What Works and Who Benefts? American Economic Journal: Economic Policy, 9(1), 180-209.

Cameron, S., \& Taber, C. (2004). Estimation of Educational Borrowing Constraints Using Returns to Schooling. Journal of Political Economy, 112, 132-182.

Chatterji, M. (1998). Tertiary Education and Economic Growth. Regional Studies, 32(4), 349-354.

Chein, F., \& Pinto, C. (2017) Credit constraint and human capital investment: an empirical analysis using Brazilian household budget survey. Applied Economics,1-17.

Cheung, H. Y., \& Chan, A. W. (2008). Corruption across countries: Impacts from education and cultural dimensions. The Social Science Journal, 45, 223-239. doi:10.1016/j.soscij.2008.03.002

Churchill, S.A., Madhoo, Y.N. \& Nath, S. (2020). Ethnic diversity and human capital development in India: A disaggregated analysis at the state and district levels. Applied Economics,52(5). 506-518.

Croix, D. d., \& Delavallade, C. (2007). Corruption et allocation optimale de l'investissement public. Revue économique, $58(2007$ (3)), 637-647. doi:10.3917/reco.583.0637

Croix, D. d., \& Delavallade, C. (2009). Growth, public investment and corruption with failing institutions. Economics of Governance, 10(3), 187-219.

Darvas, P., Gao, S., Shen, Y., \& Bawany, B. (2017). Sharing Higher Education's Promise beyond the Few in SubSaharan Africa. Washington, DC: World Bank.

Delavallade, C. (2006). Corruption and Distribution of Public Spending in Developing Countries. Journal of Economics and Finance, 30(2), 222-239.

Dridi, M. (2014). Corruption and Education: Empirical Evidence . International Journal of Economics and Financial Issues , 4(3), 476-493.

Duerrenberger, N., \& Warning, S. (2018). Corruption and education in developing countries: The role of public vs.private funding of higher education. International Journal of Educational Development , 217-225.

Egger, H., Egger,P., Falkinger, J., \& Grossmann,V. (2010). The Impact of Capital Market Integration on Educational Choice and the Consequences for Economic Growth. The World Economy ,33 (10), 1241-1268.

Epaphra, M., \& Massawe, J. (2017). Corruption, governance and tax revenues in Africa. Business and Economic Horizons, 13(4), 439-467. doi:10.15208/beh.2017.31.

Gruber, J. H. (2005). Religious Market Structure, Religious Participation, and Outcomes: Is Religion Good for You? Advances in Economic Analysis and Policy, 5(1),1-30.

Gupta, S., Davoodi, H., \& Tiongson, E. (2001). Corruption and the provision of health care and education services. In J. Arvind (Éd.), The political economy of corruption (pp. 111-141). London: Routledge.

Gyimah-Brempong, K., Paddison, O., \& Mitiku, W. (2006). Higher Education and Economic Growth in Africa. 
Journal of Development Studies, 42(3), 509-529.

Hansen, L. P. (1982). Large Sample Properties of Generalized Method of Moments Estimators. Econometrica, 50(4), 1029-1054.

Hanushek, E. A. (1992). The Trade-off between Child Quantity and Quality. Journal of Political Economy, 100(1), 84-117.

Hessami, Z. (2014). Political corruption, public procurement, and budget composition: Theory and evidence from OECD countries. European Journal of Political Economy, 34, 372-389.

Heylen, F., Schollaert, A. , Evaraert, G. and Pozzi, L. (2003). Inflation and human capital formation: theory and panel data evidence. Working Paper of the Faculty of Economics and Business Administration, Ghent University, $\mathrm{N}^{\circ} 03 / 174$.

Heyneman, S. P. (2004). Education and corruption. International Journal of Educational Development, 24(6), 637-648.

Huntington, S. P., \& Fukuyama, F. (2006). Political order in changing societies. London : Yale University Press. Jajkowicz, O., \& Drobiszová, A. (2015). The Effect Of Corruption On Government Expenditure Allocation In OECD Countries. Acta Universitatis Agriculturae et Silviculturae Mendelianae Brunensis, 63(4), 1251-1259.

Lipset, S. M. (1960). Political man: the social bases of politics. Garden City: Doubleday.

Leff, N. H. (1964).Economic development through bureaucratic corruption. American Behavioral Scientist, 8(2), 8-14.

Mauro, P. (1998). Corruption and the composition of government expenditure. Journal of Public Economics, 69, 263-279.

Mimoun, M. (2008). Credit Constraint in Education: Evidence from International Data. Journal of Applied Economics, 11, 33-60.

Mincer, J. (1996). Economic Development, Growth of Human Capital, and the Dynamics of the Wage Structure. Journal of Economic Growth, 1(1), 29-48.

Montenegro, C. E., \& Patrinos, H. A. (2014). Comparable Estimates of Returns to Schooling Around the World. Policy Research Working Paper 7020, 1-39.

Okuneye, B., \& Adelowokan, O. (2014). Tertiary Enrolment and Economic Growth in Nigeria. Journal of Economics and Sustainable Development, 5(5), 1-7.

Osipian, A. L. (2007). Corruption in Higher Education:conceptual approaches and measurement techniques. Research in Comparative and International Education, 2(4), 313-332.

Pring, C., \& Vrushi, J. (2019). Global Corruption Barometer Africa 2019: Citizens' Views and Experiences Of Corruption. Transparency International.

Rajkumar, A. S., \& Swaroop, V. (2008). Public spending and outcomes: Does governance matter? Journal of Development Economics, 86, 96-111.

Roodman, D. (2009a). A note on the theme of too many instruments. Oxford Bulletin of Economics and Statistics, $71(1), 135-158$.

Roodman, D., (2009b). How to do xtabond2: An introduction to difference and system GMM in Stata. Stata Journal, 9(1),86-136.

Rumyantseva, N.L., (2005). Taxonomy of corruption in higher education. Peabody Journal of Education, 80 (1), 81-92.

Seka, P. R. (2013). Corruption, croissance et capital humain :quels rapports ? Afrique et développement, XXXVIII(1 \& 2), 133-150.

Sen, K. (2015). Governance and development outcomes in Asia. In A. B. Deolalikar, S. Jha, \& P. F. Quising, Governance in developing Asia : Public service delivery and empowerment (pp. 78-100). Manila.

Swamy, A., Knack, S., Lee, Y., \& Azfar, O. (2001). Gender and corruption. Journal of Development Economics, 64(1), 25-55.

Transparency International. (2013). Global Corruption Report: Education. New York: Routledge.

Transparency International. (2020). Corruption Perception Index 2019.

Truex, R. (2011). Corruption, attitudes, and education : survey evidence from Nepal. World Development, 39(7), $1133-1142$.

Wang, M. (2011). FDI and human capital in the USA: is FDI in different industries created equal? Applied Economics Letters, 18 (2),163-166.

Windmeijer, F., (2005). A finite sample correction for the variance of linear efficient two-step GMM estimators. Journal of Econometrics, 126 (1),25-51.

World Bank. (2017). Higher Education for Development: Washington, DC.

World Bank. (2020a). World Development Indicators. Washington, DC.

World Bank. (2020b). Worldwide Governance Indicators. Washington, DC.

Zhuang, H. (2013). Foreign Direct Investment, Export and Rural Educational Attainment in China. International Research Journal of Finance and Economics, 114, 129-140. 
Zhuang, H. (2016). The effect of foreign direct investment on human capital development in East Asia. Journal of the Asia Pacific Economy, 22 (2), 195-211 